\title{
A Literature Review of Labor Absorption Level of Vocational High School Graduate In Indonesia
}

\author{
Anitiyo Soelistiyono ${ }^{1, *}$ Chen Feijuan ${ }^{1}$ \\ ${ }^{1}$ Department of Technological and Vocational Education Humanities and Applied Science National Yunlin University, \\ Taiwan \\ *Corresponding author. Email: anitio20@yahoo.com
}

\begin{abstract}
Employment is an essential issue in business and economic activities in Indonesia. A labour force, working population, and unemployment rate, which is the capital for the driving wheel of development. With have the knowledge and skills, vocational high school (VHS) graduates to enter the workforce after completing their education immediately. However, in reality, the open unemployment rate of vocational high school graduates still shows the highest number compared to other education levels. This literature review discusses employment in Indonesia, especially for vocational high school graduates, utilizing an employee survey conducted by the Central Bureau of Statistics. This research aims to describe and evaluate Indonesia's employment, especially in the population who have completed vocational high school. The contribution of the study to the parties involved in making recommendations in formulating policies to improve the quality of vocational high school graduates. The result of research, by gender, the number of unemployed male graduates is almost twice as high as that of women. Employment opportunities that are still limited and unable to accommodate all graduates are also thought to be one indicator of the cause of the high rate of graduate unemployment. Based on education level, workers with low education do not choose jobs and tend to accept available jobs. In the informal sector, the percentage of vocational high school graduates who work is much smaller. Male workers tend to receive higher salaries than the wages received by female workers.
\end{abstract}

Keywords: Central bureau of statistics, Employment, Vocational high school.

\section{INTRODUCTION}

\subsection{Background}

According to the Central Bureau of Statistics data, Generation Z born in 1997-2012 and the Millennial Generation born in 1981-1996 dominated most of Indonesia's population. Generation $\mathrm{Z}$ is $27.94 \%$ of the total population, and the Millennial Generation is $25.87 \%$. These two generations enter the productive age, which can be an opportunity to accelerate economic growth [1]. The Millennial generation can adapt to a new management culture, contribute to workplace innovation, balance work and leisure [2]. Because of technology, these three areas of the millennial generation's lives are considerably more intertwined than in earlier generations. The millennial generation has high expectations, is goal-oriented, and expects to find a similar culture at work because they learn in more innovative and collaborative educational systems [3]. The millennial generation has values like optimism, civic duty, confidence, achievement, sociability, morality, and smarts. The millennial generation desires a flexible work schedule and feels like they contribute to something bigger than themselves, which they frequently rank higher than salary [4].

In several parts of economic research, the process to understand age-productivity profiles is vital to avoid unemployment. Ageing workers can decrease economic growth and decrease fiscal sustainability because ageing workers are not very productive again. Senior workers have higher wages more than their productivity levels, and to improve their employability, we need to reduce their salaries. So that to improve the retirement age to be successful, the system of seniority and wage needs to be removed. [5].

When Indonesia has the number of productive age generations, Indonesia will have high competitiveness and bargaining power. This condition will make investors more interested in spending their money, automatically opening up more job opportunities. [6]. The demographic does not include the Asean Economic Community (MEA), making the competition to find work in Indonesia even tougher [7]. In most developing nations, an increase in the working-age population has 
accompanied a decrease in fertility, creating an opportunity [8]. The transformation of the age structure of a country's population can change and increase and accelerate economic growth [9].

On the other hand, a demographic disaster will occur if the available human resources are not qualified to make people of productive age become unemployed, given the limited employment opportunities and will increase competition among job seekers. Therefore, fair competition for labour skills in the era of free competition is required to improve the quality of education and develop learning concepts that significantly increase skills or competencies. Next is the relevance of vocational high school graduates to the world of work. Therefore, this literature review research explores employment in Indonesia, especially for vocational high school graduates, from 2015 until 2020.

Finally, the study results provide a more detailed picture of the profile, description, conditions, patterns, and tendencies of vocational high school graduates studying in the labour market.

\subsection{Research Purpose}

This research aims to describe and evaluate Indonesia's employment, especially in the population who have completed vocational high school. The contribution of this literature review study is that the parties involved in making recommendations can use the results of this literature review in formulating policies to improve the quality of human resources for vocational high school graduates. Furthermore, prepare vocational high school graduates and become experts and skilled workers ready to work and develop knowledge related to employment.

\section{RESEARCH METHODOLOGY}

\subsection{Data Sample}

The data used in this literature review is microdata of the national employment survey, processed by the Central Bureau of Statistics. The national employment survey is a particular survey to collect employment data specifically designed to collect the necessary employment data that can describe the general state of employment conditions in a period. In general, the purpose of the national employment survey is to provide essential employment data and obtain information relating to the number of people working, the number of unemployed people, and people who have quit or moved from their jobs, as well as the condition of population development at the district, provincial, and local, national levels. [10].

\subsection{Research Method}

The design of this research is a descriptive quantitative method. Descriptive research is a quantitative research method that attempts to collect quantifiable information for statistical analysis of the population sample.

\subsection{Analysis Method}

This study uses descriptive statistical analysis. Descriptive analysis is a part of statistical science that summarizes, presents, and describes data in an easy-toread form to provide complete information. Descriptive statistics is a data analysis process to make it easier for readers to understand a problem in research by describing the problem through data collection and presentation that aims to provide clear and valuable information [11].

\section{RESULTS AND DISCUSSION}

\subsection{Employment Opportunities for Vocational High School Graduates}

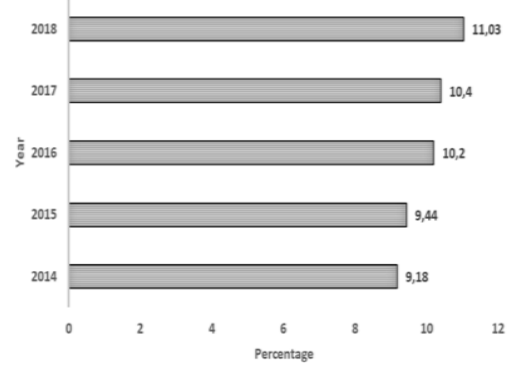

Figure 1 Opportunities to employment for the student of vocational high school that has completed. [12]

Based on Figure 1, data on the number of VHS graduates who have completed their studies always increase every year, and that experienced the most significant increase was in 2018 is $11.03 \%$. With a high percentage, VHS graduates still dominate the allocation of Indonesian workers. Interestingly, the prediction of VHS graduates to be ready to enter the workforce contribute less labour than graduates from other school levels. The increase in the number of new vocational schools that do not through prior feasibility studies makes it difficult for VHS graduates to find work.

The results contradict the other study results, which states that the government makes many new building schools, but the government conducts less survey whether the development is feasible. The impact of this situation is that the graduates have the challenging experience to get a job in the labour market. The approach that government conduct tended to be theoretical and tended less relevant. Furthermore, they faced some the challenges such as inadequate facilities, industry support, and teachers[13].

\subsection{Percentage of unemployed vocational high school graduates in Indonesia}

An important issue that needs the government's attention is unemployment. The amount of 
unemployment will affect the amount of labour force participation in the economic activities of a country or region. Furthermore, at the same time, they are not working. So then, we can call unemployment with this concept or definition open unemployment.

As shown in Figure 2, the unemployment contribution of VHS graduates to national unemployment has continuously been increasing. The Data shows that the most significant percentage of VHS unemployment occurring in 2018 was $24.74 \%$, increasing $6.35 \%$ compared to the unemployment contribution in 2014.

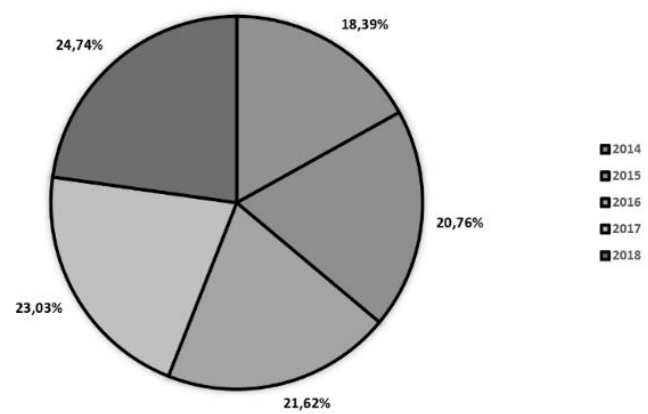

Figure 2 Percentage of vocational high school graduates in Indonesia (\%) Source: processed Central Bureau of Statistics data [14]

The other research states that the national average of graduates from senior high schools compared to VHS was 62.92 percentage: $37.08 \%$ percentage in 2016 . However, according to 2019 data, the comparison is 63.39 percentage: 36.61 percentage. Furthermore, the national average unemployment rate of senior high school graduates compared to VHS is 8.72 percentage: 11.11 ratio in 2016, and according to 2019 data, it is 7.92 percentage and 10.42 percentage. Thus, the results of this comparison show that the unemployment rate for graduates of VHS has a higher percentage rate when compared to graduates of senior high schools [15].

\subsection{Unemployment of Vocational High Education graduates in Indonesia by Gender}

The national unemployed number of VHS graduates tends to increase every year until 2018, which reached 1.7 million people.

Based on gender, the number of unemployed male graduates is almost twice that of women. The number of male students graduating from VHS is also more significant than that of female students graduating. In general, the unemployed in the two groups experienced a fluctuating pattern from year to year, with the highest number of unemployed occurring in 2018, which reached around 1.1 million men and 566 thousand women.

Mahroza [16] stated that the gender variable has a positive and statistically significant effect on unemployment opportunities for VHS graduates. In this study, female vocational school graduates will increase the chance to be unemployed more than men.

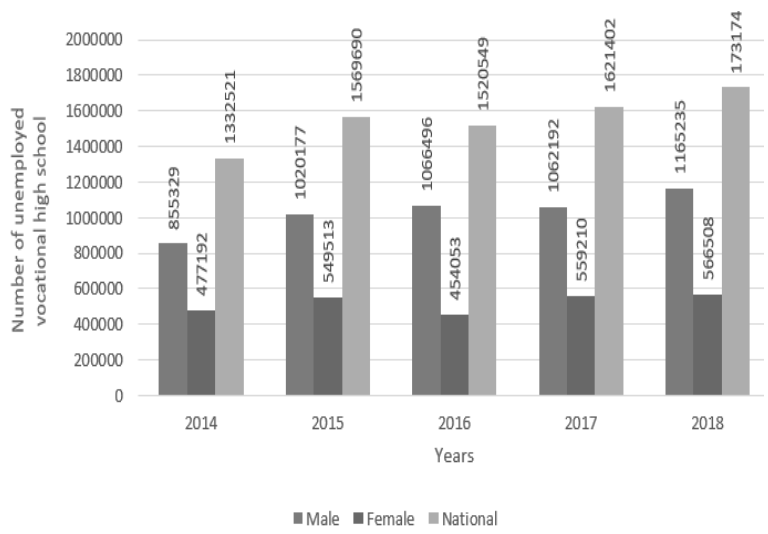

Figure 3 Unemployment of Vocational High Education graduates in Indonesia by Gender. Source: processed Central Bureau of Statistics data [14]

\subsection{Open Unemployment Rate by Highest Education Level}

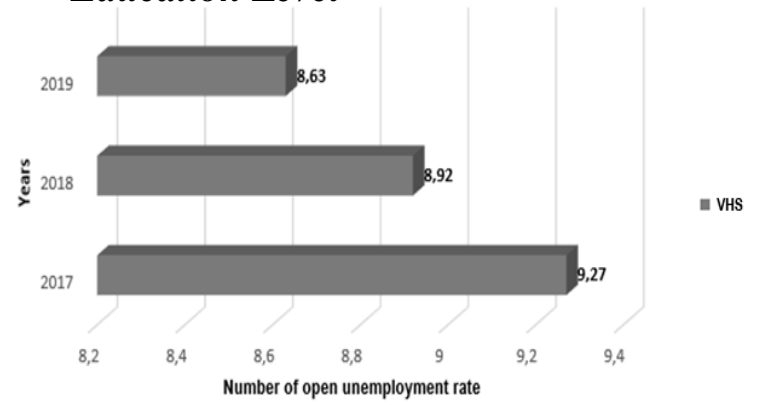

Figure 4 Description of open unemployment rate based on highest education level. Source: Processed from national labour force survey of vocational high school data for the period 2017-2019

When viewed based on the level of education shown in Figure 4, the open unemployment rate of graduates from VHS, although the percentage has decreased, the speed of available unemployment rate for graduates from this level of education is still at the highest value among other levels of education. Nevertheless, the high unemployment rate for these graduates is one indicator that shows that the competitiveness of this level of graduates in the world of work is still not satisfactory.

Employment opportunities in Indonesia, which are still limited and unable to accommodate all VHS graduates who enter the workforce, are also thought to be one indicator of the cause of the high unemployment rate for vocational high school graduates.

It is supported the other study stated that the available job opportunities were not proportional to the number of job seekers, resulting in very tight competition and causing the number of young unemployed to increase. [17]. 


\subsection{Working Population Based on Education Level}

Figure 5 below showed that the percentage of the working population according to the highest education in the period 2017 to 2019. Labour absorption in that period for VHS graduates is lower than the percentage of workers who graduate from elementary school, junior high school, and senior high school.

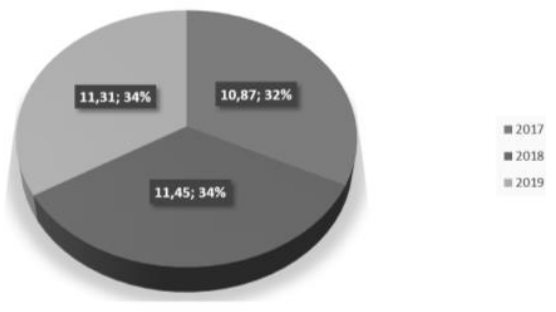

Figure 5 Percentage of Working Population by Highest Education Completed for the period 2017-2019. Source: processed Central Bureau of Statistics data 2017, 2018, and 2019

On the other hand, the rate of graduates from VHS is higher than that of graduates from university and Diploma. The percentage of the population working VHS graduates in 2019 was $11.31 \%$, indicating an increase in employment rate by $0.44 \%$ compared to 2017 and a decrease of $0.53 \%$ compared to 2018 .

A result of one research stated that Low levels of education had a higher chance of unemployment. In addition, there is an effect of education on employment related to the total unemployment rate and the gender of job applicants. [18].

\subsection{The Contribution of the Working Population of Vocational High School Graduates to the Total Working Population by Formal/Informal Activities}

Figure 6 provides an overview of the population working in the informal sector more than the population working in the formal sector. The working population of VHS graduates in this sector is only $6.91 \%$ of the total population working in the informal sector.

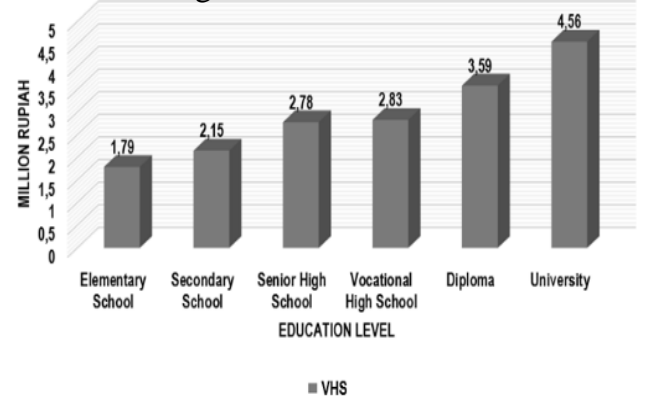

Figure 6 Contribution of the Working Population of Vocational High School Graduates to the Total Working Population by Formal/Informal Activities in 2018. Source: processed Central Bureau of Statistics data [14]
For the condition that the formal sector has not been able to absorb and has not been able to provide opportunities for job seekers, the informal sector can significantly contribute to the economy. However, official statistics do not regularly publish statistical data relating to the informal sector's labour force and employment. Thus, Indonesia's informal sector has not yet benefited from well-informed policies. [19].

\subsection{Average Wages of Labor/Employees by Vocational High School Graduated and Gender in 2019}

Based on figure 7, according to the highest education completed, the average workers in Indonesia received wages of workers by 2.73 million rupiahs, where male workers tend to receive higher salaries than women workers. The male workers received an average salary of 2.96 million rupiahs, about $30 \%$ higher than the female workers who only received a wage as big as 2.19 million rupiahs.

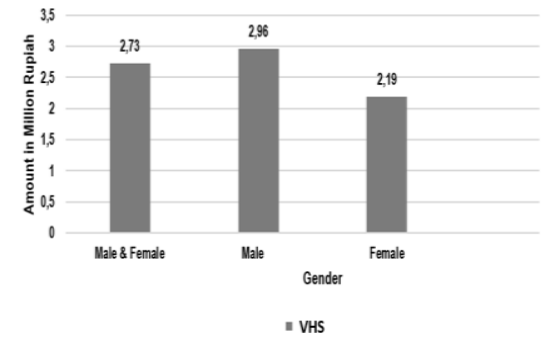

Figure 7 Average Wages of Labor by Highest Education Graduated and Gender for 2019. Source: processed Central Bureau of Statistics data [20]

According to the other study's findings, the earnings discrepancy between vocational and academic education is as high as $19 \%$ for men and $21.7 \%$ for women, with a minor negative gap in employment. Thus, in general, vocational education does not do as well as academic education in terms of income. In addition, when the labour market considers employability, vocational education performed somewhat better than academic education. [21].

\subsection{Average Wages of Labor/Employees by Highest Education Graduated in 2020}

Based on Figure 8, the average wages of labour or employees by vocational high school are lower than diploma and university graduates but still higher than the average wages of labour or employees by elementary school, secondary school, and senior high school.

This argument contradicts Psacharopoulous (1993) research, which showed that the social rate of return for investment in vocational education shows a lower value 
than the value of general secondary education. This value is mainly because vocational secondary education has to provide much higher costs.

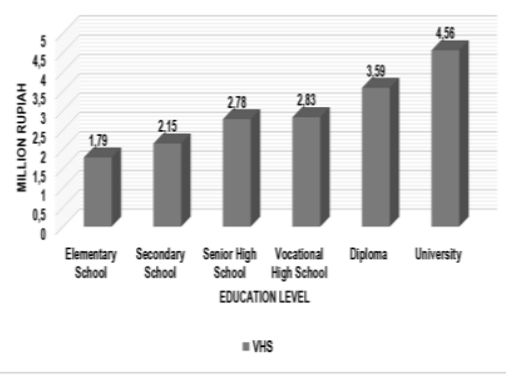

Figure 8 Average Labor Wages by Higher Education Graduated for the 2020 Period. Source: processed Central Bureau of Statistics data [22].

\subsection{Discussion}

Based on Figure 1, the number of VHS graduates who have completed their studies shows an increase every year. Interestingly, predictions from VHS graduates who are ready to enter the workforce show that the workforce's contribution is less than graduates from other school levels.

However, at the data in Figure 2, the most significant percentage of VHS unemployment in 2018 compared to the unemployment in 2014. In contrast to the unemployment of VHS graduates, the percentage of unemployed graduates of non-VHS has decreased significantly. This Data assumes that the imbalance between VHS graduates and the number of available jobs causes many VHS graduates to be unabsorbed in existing jobs, causing much unemployment. It was supported by the opinion of Deprince and Morris [23], which states that there is a mismatch between the demand side and the supply side of labour, causing educated unemployment.

Based on figure 7 shows that the average labour wages employment of males is more significant than females. Moreover, figure 8 shows that the highest education graduates, such as diplomas and university, have the average wages of labour or employees more increased than the number of average wages or employees by VHS. However, the average salaries of workers or employees by VHS are lower than diploma and university graduates but still higher than the average wages of labour or employees by elementary school, secondary school, and senior high school. This information assumes that the opportunities of male graduates are still bigger than females in the workplace. The VHS still has the average wages in high education levels.

Maybe the VHS opportunity in the informal and formal workplace is still less than the national chance to get a job in the workplace, as stated in figure 6 . This information indicated that the VHS graduates have to increase their ability, experience, and struggle to get an excellent job. According to figure 7, shows that the male gender tends to receive a higher salary. Figure 8 shows that although the average wage for vocational workers or employees is lower than diploma and university graduates, it is still higher than the average wage for elementary, junior high, and senior high school workers. Nevertheless, these results contradict Psacharopoulous \& Patrinos [24] previous research, which showed that the social rate of return for investment in vocational education shows a lower value than general secondary education because vocational secondary education has to provide much higher costs. These findings assume that the average wages of labour employees of VHS graduates is more increased in the rate but have seen the social rate of investment return. Because the social rate of return for the investment of VHS shows a lower value.

\section{CONCLUSION}

Therefore, an important issue that needs the government's attention is unemployment. The amount of labour force participation will significantly affect the number of unemployed in the economic activities of a country or region. When viewed by gender, the number of unemployed male graduates is almost twice as high as that of women. In addition, many graduates cannot compete with graduates of other education levels, so that graduates become openly unemployed.

Employment opportunities in Indonesia, which are still limited and unable to accommodate all graduates who enter the workforce, are also thought to be one indicator of the cause of high unemployment rate for graduates. The assumption with a high percentage of the working population is that workers with low education do not choose a job and tend to accept any available job.

On the other hand, although the percentage of employment for VHS graduates is lower than the percentage of workers who graduate from elementary school, junior high school, and senior high school, the graduates from VHS are higher than that of graduates from university and Diploma. Meanwhile, the percentage of VHS graduates who work in the informal sector is much smaller.

The average wage received by workers in Indonesia is 2.79 million rupiahs, where male workers tend to receive higher salaries than the wages received by female workers. The difference in wages received is indicated to occur because generally, male workers are in higher sectors and job functions than female workers. Male workers dominate work fields that offer high salaries, such as in the technology sector, while many female workers are in industries that provide not such high wages. In addition, female workers also tend to choose jobs with fewer hours of part-time work for family reasons.

\section{Implication}

Employment opportunities are still limited and have not been able to accommodate all graduates, which is one indicator of the cause of the high unemployment rate for VHS graduates. In addition, many graduates cannot 
compete with graduates of other education levels, causing them to become openly unemployed. Moreover, not all VHS graduates have the same quality in skills, expertise, and insight, so it is necessary to determine the quality standards of VHS students. In addition, VHS graduates' skills are still not following the needs of the labour market, so they still need adjustment to the world of work. In addition, there are limitations of vocational graduates in receiving job information cause VHS graduates need more job information.

\section{REFERENCES}

[1] Putri, "Indonesia Saat ini Masih Berada di Era Bonus Demografi," Info Publik, 2021. [Online]. Available: https://infopublik.id/kategori/nasionalsosial-budaya/504464/indonesia-saat-ini-masihberada-di-era-bonus-demografi.

[2] S. Y. Chou, "Millennials in the Workplace: A Conceptual Analysis of Millennials' Leadership and Followership Styles," Int. J. Hum. Resour. Stud., vol. 2, no. 2, p. 71, 2012, DOI: 10.5296/ijhrs.v2i2.1568.

[3] R. Appel Muelenbroek and B. P. Haynes, "The impact of generational differences on the workplace," J. Corp. Real Estate, vol. 13, no. 2, pp. 98-108, 2011, DOI: 10.1108/14630011111136812.

[4] S. D. Smith and Q. Galbraith, "Motivating Millennials: Improving Practices in Recruiting, Retaining, and Motivating Younger Library Staff," J. Acad. Librariansh., vol. 38, no. 3, pp. 135-144, 2012, DOI: 10.1016/j.acalib.2012.02.008.

[5] V. Skirbekk, "Age and Individual Productivity: A Literature Survey," Vienna Yearb. Popul. Res., vol. 1, no. 2004, pp. 133-154, 2004, DOI: 10.1553/populationyearbook2004s 133 .

[6] R. Lee and A. Mason, "Population aging and the generational economy: A global perspective," Popul. Aging Gener. Econ. A Glob. Perspect., vol. 2, no. 1, pp. 220-222, 2011, DOI: 10.25336/p60034.

[7] Maucash, "Apa Yang Akan Terjadi dengan Ekonomi Indonesia?," 2020. [Online]. Available: https://maucash.id/https-maucash-id-bonusdemografi-indonesia-2030.

[8] D. E. Bloom, D. Canning, G. Fink, and J. Finlay, "PROGRAM ON THE GLOBAL DEMOGRAPHY OF AGING Realizing the Demographic Dividend: Is Africa any different? Realizing the Demographic Dividend: Is Africa any different? 1," no. July 2007.

[9] A. Hayes and D. Setyonaluri, Taking Advantage of The Demographic Dividend in Indonesia: A Brief Introduction to Theory and Practice, no. April. 2015.

[10] CBS, “sakernas98pedoman.pdf,” Jakarta, 1998.

[11] V. Y. Parampreet Kaur, Jill Stoltzfus, "Descriptive statistics," IJAM-International J. Acad. Med., vol.
4, no. 1, pp. 60-63, 2018, doi: 10.4103/IJAM.IJAM_7_18.

[12] H. Gusman, "43\% Tenaga Kerja Lulusan SD \& SMP, Apa Indonesia Siap Industri 4.0?," Tirto.id, 2019. [Online]. Available: https://tirto.id/43tenaga-kerja-lulusan-sd-smp-apa-indonesia-siapindustri-40-djZj.

[13] Suharno, N. A. Pambudi, and B. Harjanto, "Vocational education in Indonesia: History, development, opportunities, and challenges," Child. Youth Serv. Rev., vol. 115, no. May, p. 105092, 2020, DOI: 10.1016/j.childyouth.2020.105092.

[14] CBS, "Booklet Survei Angkatan Kerja Nasional Agustus 2018," Jakarta, 2018.

[15] E. Ohara, S. P. Harto, and R. F. Maruanaya, "Policy Shift to Reduce Unemployment of Vocational School Graduates in Indonesia (A National Study)," J. Pendidik. Teknol. dan Kejuru., vol. 26, no. 2, pp. 129-139, 2020, doi: 10.21831/jptk.v26i2.33144.

[16] A. D. Mahroza, "Determinant of Vocational High School's Open Unemployment," vol. 4, no. 2, pp. 1188-1200, 2021.

[17] S. Ubaidah, S. Trisnamansyah, H. S. Insan, and N. Harahap, "Partnership Management Between Vocational Schools with the World of Business and Industry to Improve the Quality of Graduates Who Are Ready to Work," Int. J. Nusant. Islam, vol. 9, no. 1, pp. 58-69, 2021, DOI: 10.15575/ijni.v9i1.11818.

[18] M. H. J. Wolbers, R. Luijkx, and W. Ultee, "Educational attainment, occupational achievements, career peak: The Netherlands in the second part of the twentieth century," Eur. Soc., vol. 13, no. 3, pp. 425-450, 2011, DOI: 10.1080/14616696.2011.568265.

[19] S. Cuevas, C. Mina, M. Barcenas, and A. Rosario, "Informal employment in Indonesia," $A D B$ Econ. Work. Pap. Ser., vol. 156, no. 156, pp. 1-44, 2009 , DOI: $10.2139 /$ ssrn.1611406.

[20] CBS, "Booklet Survei Angkatan Kerja Nasional Agustus 2019," Jakarta, 2019.

[21] G. Brunello and L. Rocco, "The effects of vocational education on adult skills, employment, and wages: What can we learn from PIAAC?," SERIEs, vol. 8, no. 4, pp. 315-343, 2017, DOI: 10.1007/s13209-017-0163-z.

[22] CBS, "Rata-rata Upah Buruh Perbulan Februari 2020," Jakarta, 2020.

[23] B. A. E. Deprince and P. D. Morris, "Education on the Unemployment," no. April, pp. 45-54, 2008.

[24] G. Psacharopoulos and H. A. Patrinos, "Secondary vocational education and earnings in Latin America," Vocat. Asp. Educ., vol. 45, no. 3, pp. 229-238, 1993 , $10.1080 / 0305787930450304$. 